\title{
Detection of genetic diversity of Anaplasma marginale isolates in Minas Gerais, Brazil
}

\author{
Detecção de diversidade genética de isolados Anaplasma marginale em Minas Gerais, Brasil \\ Anna Elisabeth Pohl ${ }^{1}$; Alejandro Cabezas-Cruz²; Múcio Flávio Barbosa Ribeiro ${ }^{3}$; Júlia Angélica Gonçalves da Silveira ${ }^{3}$; \\ Cornelia Silaghi; Kurt Pfister ${ }^{1}$;ygia Maria Friche Passos ${ }^{1,4^{*}}$ \\ ${ }^{1}$ Institute for Comparative Tropical Medicine and Parasitology, Ludwig-Maximilians-Universität - LMU, 80752, München, Germany \\ ${ }^{2}$ Biology Centre of the Academy of Sciences of the Czech Republic, v. v. i. , Parasitology Institute - IP, Faculty of Science, \\ University of South Bohemia, 370 05, České Budějovice, Czech Republic \\ ${ }^{3}$ Departamento de Parasitologia, Instituto de Ciências Biológicas - ICB, Universidade Federal de Minas Gerais - UFMG, \\ Belo Horizonte, Brazil \\ ${ }^{4}$ Departamento de Medicina Veterinária Preventiva, Instituto Nacional de Ciência e Tecnologia - INCT/Informação Genético-sanitária \\ da Pecuária Brasileira, Escola de Veterinária, Universidade Federal de Minas Gerais - UFMG, Belo Horizonte, MG, Brazil
}

Received December 6, 2012

Accepted February 18, 2013

\begin{abstract}
Bovine anaplasmosis, caused by the tick-borne rickettsia Anaplasma marginale, is endemic in tropical and subtropical regions of the world and results in economic losses in the cattle industry. Major surface proteins (MSPs) have been used as markers for the genetic characterization of $A$. marginale strains and demonstrate that many isolates may occur in a given geographic area. However, in Brazil, little is known about the genetic diversity of $A$. marginale isolates within individual herds. This study was designed to examine the genetic variation among $A$. marginale infecting calves in a farm in the south of Minas Gerais State, Brazil. Blood samples collected from 100 calves were used to prepare Giemsastained smears that were microscopically examined for the presence of $A$. marginale. From each blood sample, DNA was extracted and analyzed by a polymerase chain reaction (PCR), followed by sequencing to determine diversity among the isolates. Examination of blood smears showed that $48 \%$ of the calves were infected with $A$. marginale, while the real-time PCR detected $70.2 \%$ positivity. Congenital infections were found in four calves. The microsatellite and tandem repeat analyses showed high genetic diversity among the isolates.
\end{abstract}

Keywords: Anaplasma marginale, MSP1a, DNA sequencing, microsatellites, tandem repeats, Brazil.

\section{Resumo}

A anaplasmose bovina, causada pela rickettsia Anaplasma marginale e transmitida por carrapatos, é endêmica em regióes tropicais e subtropicais no mundo e causa grandes perdas econômicas na industria de bovinos. Proteínas principais de superfície (MSPs) foram usados como marcadores para a caracterização genética de amostras de A. marginale, demonstrando que diferentes isolados podem ocorrer numa certa região geográfica. Porém, no Brasil pouco se sabe sobre a variedade genética de isolados de $A$. marginale em rebanhos individuais. Este estudo teve como objetivo investigar a ocorrência de variação genética entre bezerros infectados com $A$. marginale numa fazenda do sul de Minas Gerais, Brasil. Amostras de sangue coletadas de 100 bezerros foram utilizadas para o preparo de esfregaços sanguíneos, corados pelo Giemsa, para detecção da infecção por A. marginale. Amostras de DNA extraídas de cada amostra foram analisadas através de PCR seguido de sequenciamento. O exame dos esfregaços demonstrou que 48\% dos bezerros estavam infectados com $A$. marginale, enquanto que o PCR detectou 70,2\% de positividade. Infecção congênita foi detectada em quatro bezerros. As análises de microsatélites e 'tandem repeats' comprovaram uma grande diversidade genética entre os isolados.

Palavras-chave: Anaplasma marginale, MSP1a, sequenciamento de DNA, microsatélites, tandem repeats, Brasil.

\footnotetext{
${ }^{*}$ Corresponding author: Lygia Maria Friche Passos

Institute for Comparative Tropical Medicine and Parasitology,

Ludwig-Maximilians-Universität - LMU, 80752, München, Germany

e-mail: lygiapassos@yahoo.com
} 


\section{Introduction}

Anaplasmosis is a tick-borne disease of ruminants, caused by the obligate intra-erythrocytic bacterium Anaplasma marginale with a widespread distribution in tropical-to-temperate climates (AUBRY; GEALE, 2011). Ticks are the biological vectors of $A$. marginale and the one-host tick Rhipicephalus (Boophilus) microplus is considered to be the main vector in Brazil (KESSLER; SCHENK, 1998). The pathogen can also be transmitted mechanically by biting flies, blood-contaminated fomites, or congenitally by transplacental transmission (ZAUGG; KUTTLER, 1984; PASSOS; LIMA, 1984). Transplacental transmission of $A$. marginale may therefore contribute to the epidemiology of this disease in some regions (KOCAN et al., 2003). Cattle of all ages can become infected and remain persistently infected carriers for life, with clinical signs varying from asymptomatic to acute cases with fever, anaemia, abortion, weight loss, lowered milk production or death (KESSLER; SCHENK, 1998; RIBEIRO; PASSOS, 2002).

Direct diagnosis can be made by microscopic examination of Giemsa-stained blood smears, but this method can only detect levels of $>10^{7}$ infected erythrocytes per $\mathrm{ml}$ of blood (PALMER et al., 2000).

For epidemiological surveys, indirect and direct methods, such as the Indirect Fluorescent Antibody Test (IFAT) and the real-time PCR are more appropriate to reveal the status of a herd.

Brazil is considered to be an endemic area where calves, being less susceptible to clinical disease than adults, acquire the infection shortly after birth which seems to be an important factor for endemic stability (AUBRY; GEALE, 2011). However, although anaplasmosis is endemic in Minas Gerais State, the occurrence of outbreaks causes huge economic losses to the cattle industry (RIBEIRO; REIS, 1981).

Many different geographic strains of $A$. marginale have been identified, which differ as regards to biology, genetic characteristics and transmissibility by ticks (DE LA FUENTE et al., 2005, 2007). The $A$. marginale major surface protein 1a (MSP1a) was shown to be involved in vector-pathogen and host-pathogen interactions and to have evolved under positive selection pressure (DE LA FUENTE et al., 2003a). Among different strains, the MSP1a differs in molecular weight due to a variable number of tandem 23- to 31-amino-acid repeats, and it has been proven to be a stable marker of strain identity (ESTRADA-PENAA et al., 2009).

The understanding of $A$. marginale epidemiology, including the characterization of the genetic diversity of strains in a region, provides knowledge for the development and implementation of control measures.

Therefore the aim of the present study was to determine the occurrence of genetic diversity within a herd in a dairy farm in Brazil.

\section{Materials and Methods}

\section{Samples and microscopic examination}

The study was carried out from December 2010 to January 2011 on a dairy farm located near Cordislândia (latitude $21^{\circ} 79^{\prime}$ longitude $45^{\circ}$ 67', 816 m), in Minas Gerais State, Brazil. Blood samples were collected from the jugular vein into EDTA from all the calves (100) on the farm, which were of the breeds Holstein, Jersey and crossbreed. The calves were classified into 4 groups according to their ages: Group 1 (17 calves from 1 to 7 days old), Group 2 (12 calves from 8 to 30 days old), Group 3: (15 calves from 31 to 107 days old) and Group 4: (56 calves from 108 to 381 days old). Giemsa-stained blood smears were prepared and bacteremia was calculated as the percentage of $A$. marginale infected erythrocytes detected in 20 microscopic fields.

\section{Genomic DNA isolation and PCR}

DNA was extracted from 94 blood samples using the commercial Wizard $^{\circledast}$ Genomic DNA Purification kit according to the manufacturer's instructions (Promega, Madison, USA). DNA concentrations were determined using the spectrophotometer NanoDrop ND-1000 (PepLab, Erlangen, Germany). For the initial screening a real-time PCR was used, as reported by CARELLI et al. (2007) with modifications for targeting the msp1 $\beta$ gene. All amplifications were performed in a 7500-fast-Real-Time PCR System (Applied Biosystems, Darmstadt, Germany) and were carried out in a $25 \mu \mathrm{L}$ reaction mixture containing $5 \mu \mathrm{L}$ of DNA template, $15 \mu \mathrm{L}$ TaqMan ${ }^{\oplus}$ Gen Expression Master Mix (Applied Biosystems, USA), $2.25 \mu \mathrm{L}(10 \mu \mathrm{M})$ of each primer (AMforward: 5' TTGGCAAGGCAGCAGCTT 3' and AM-reverse: 5' TTCCGCGAGCATGTGCAT $\left.3^{\prime}\right)$ and $0.501(10 \mu \mathrm{M})$ of the probe (AM-probe: 6FAM-5'-TCGGTCTAACATCTCCAGGCTTTCAT3'-BHQ1). Cycling was performed under the following conditions: $2 \mathrm{~min} / 50^{\circ} \mathrm{C} ; 10 \mathrm{~min} / 95^{\circ} \mathrm{C}$ and 40 cycles of $15 \mathrm{sec} / 95^{\circ} \mathrm{C}$ and $1 \mathrm{~min} / 60^{\circ} \mathrm{C}$.

For sequencing, 13 positive samples from calves of different ages were selected and further analyzed by a hemi-nested PCR targeting the mspl $\alpha$ gene following the protocol of Lew et al. (2002). Reactions were performed in an automated DNA thermal cycler (Eppendorf Mastercycler ${ }^{\oplus}$, gradient) using the primers 1733F (5' TGTGCTTATGGCAGACATTTCC 3'), 3134R (5' TCACGGTCAAAACCTTT GCTTACC 3') and 2957R (5' AAACCTTGTAGCCCCAACTTATCC 3'). The primary amplification cycle, following an initial denaturation at $94^{\circ} \mathrm{C}$ for 5 minutes, consisted of 40 cycles at $94^{\circ} \mathrm{C}$ of 30 seconds, 1 minute at $55^{\circ} \mathrm{C}$ and 2 minutes at $72{ }^{\circ} \mathrm{C}$, followed by a final extension step for $7 \mathrm{~min}$ at $72{ }^{\circ} \mathrm{C}$. The same conditions were used in the second amplification cycle except that the annealing temperature was changed to $60{ }^{\circ} \mathrm{C}$. For visualization, PCR products were electrophoresed on a $2 \%$ agarose gel stained with Gel Red $^{\circledast}$ (Biotium, USA). In addition, amplified fragments were purified using a commercial kit (QIAquick PCR purification Kit, Qiagen, Hilden, Germany) and sent for sequencing of both strands (Eurofins, MWG, Operon, Ebersberg).

\section{DNA sequence analysis}

All MSP1a sequences of $A$. marginale isolates from Minas Gerais available in GenBank were included for the genetic diversity analysis. A microsatellite was located in the MSP1a 
5'UTR between the putative Shine-Dalgarno sequence (GTAGG) and the translation initiation codon (ATG). The structure of the microsatellite (bold) was GTAGG (G/A TTT)m (GT)n T ATG (ESTRADA-PEÑA et al., 2009). The UFMG-1 and UFMG-2 isolates were not included in the microsatellite analysis because the 5'UTR was missing. The tandem repeat analysis was performed following the nomenclature proposed by De La Fuente et al. (2007).

The database nucleotide collection (nr/nt) using the Megablast (optimized for highly similar sequences) from the BLAST server (http://blast.ncbi.nlm.nih.gov/) was applied to find homologies with our sequences. Nucleotide sequences were aligned using BLAST (ZHANG et al., 2000) and protein sequences were aligned using the multiple-alignment program CLUSTALW (THOMPSON et al., 1994). Nucleotide sequences were translated to amino acid (aa) sequence by the ExPASy translation tool of the Swiss Institute of Bioinformatics (EXPASY TRANSLATION TOOL, 2011).

The phylogenetic analysis was performed as follows: nucleotide sequences were aligned with MUSCLE (v3.7) configured for highest accuracy (EDGAR, 2004). After alignment, ambiguous regions (i.e., containing gaps and/or poorly aligned) were removed with Gblocks (v0.91b) (CASTRESANA, 2000). The phylogenetic tree was reconstructed using the maximum likelihood method implemented in the PhyML program (v3.0 aLRT) (GUINDON; GASCUEL, 2003, ANISIMOVA; GASCUEL, 2006). Reliability for internal branch was assessed using the bootstrapping method (100 bootstrap replicates). Graphical representation and editing of the phylogenetic tree were performed with TreeDyn (v198.3) (CHEVENET et al., 2006).

\section{Results}

\section{Detection of $A$. marginale infections}

A. marginale could be detected by microscopic examination of blood smears in 48 out of 100 animals (48\%) with bacteremia ranging from 0.1 to $16.1 \%$.

The results obtained by real-time PCR showed that 66 out of 94 animals (70.2\%) were positive for $A$. marginale and were thus this method was more sensitive than direct examination of blood smears. A. marginale infection was detected in all the age groups.
Unexpectedly, congenital infection was detected in four 1-day old calves. All four calves were positive in the hemi-nested PCR and in the real-time PCR. Only one of them was negative by blood smear examination.

Table 1 shows the percentage of animals in each age group that were positive by blood smear and in the real-time PCR. From the MSP1a PCR an amplicon of approximately $0.8 \mathrm{~Kb}$ was isolated corresponding to the expected size of the targeted $m s p 1 \alpha$ gene fragment (Table 2).

\section{MSP1a microsatellite analysis}

The analysis of MSP1a microsatellite sequences resulted in five different genotypes amongst $A$. marginale strains from Minas Gerais (Table 3). The different microsatellite sequences produced SD-ATG distances between 19 and 23 nucleotides (Table 3). The predominant genotype was $\mathbf{E}$ and it was distributed among animals of different ages and breeds (Table 4). In sequences previously reported from Minas Gerais, the genotypes $\mathbf{G}, \mathbf{D}, \mathbf{C}$ and $\mathbf{E}$ were found (DE LA FUENTE et al., 2002). Genotype $\mathbf{C}$ was not found in the present study and genotype $\mathbf{B}$ is reported for the first time in Minas Gerais isolates.

\section{MSP 1a tandem repeats and phylogenetic analysis}

Differences were found in the tandem repeat sequences and in the structure of the gene msp $1 \alpha$ among the different isolates from Minas Gerais. One MSP1a tandem repeat resulted in a new sequence with amino acid changes as shown in Figure 1. Twenty four different tandem repeats were found in all the analyzed sequences (Figure 2). Nine of them were not previously reported

Table 1. Positivity (\%) for Anaplasma marginale detected by direct examination (blood smears) and by molecular analysis (RT-PCR) from Minas Gerais State.

\begin{tabular}{ccc}
\hline $\begin{array}{c}\text { Group } \\
\text { (age range in days) }\end{array}$ & $\begin{array}{c}\text { + Blood smears } \\
(\mathbf{\%})\end{array}$ & $\begin{array}{c}\text { + RT-PCR } \\
(\%)\end{array}$ \\
\hline $1(1-7)$ & 17.6 & 25 \\
$2(8-30)$ & 8.3 & 16.7 \\
$3(31-107)$ & 46.7 & 61.5 \\
$4(108-381)$ & 67.9 & 98.1 \\
\hline
\end{tabular}

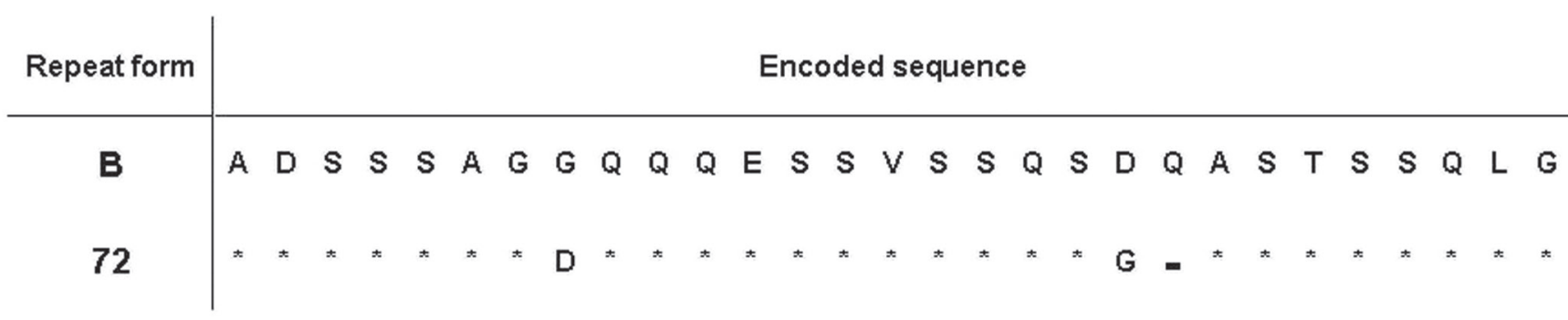

Figure 1. New sequence of MSP1a tandem repeat (72) found in A. marginale isolates from Minas Gerais. The one letter amino acid code was used to depict the differences found in MSP1a repeats. Asterisks indicate identical amino acids and gaps indicate deletion/insertions. The repeat form B was taken as a model to compare the new repeat. 
Table 2. Isolates of $A$. marginale from Minas Gerais, Brazil included in the study.

\begin{tabular}{lclcc}
\hline Isolate & Age (days) & Breed & Age group & GenBank accession number \\
\hline Minas-1 & 0 & Holstein & 1 & JX844205 \\
Minas-2 & 1 & Jersey & 1 & JX844206 \\
Minas-3 & 1 & Holstein & 1 & JX844207 \\
Minas-4 & 1 & Jersey & 1 & JX844208 \\
Minas-5 & 14 & Jersey & 2 & JX844209 \\
Minas-6 & 29 & Jersey & 2 & JX844210 \\
Minas-7 & 40 & Jersey & 2 & JX844216 \\
Minas-8 & 78 & Jersey & 3 & JX844211 \\
Minas-9 & 78 & Holstein & 3 & JX844217 \\
Minas-10 & 103 & Holstein & 3 & JX844212 \\
Minas-11 & 253 & Jersey & 4 & JX844213 \\
Minas-12 & Jersey & 4 & JX844214 \\
Minas-13 & 355 & Jersey & N/D & JX844215 \\
Brazil & N/D & N/D & N/D & AF428092 \\
Brazil-5 & N/D & N/D & N/D & AY283198 \\
Brazil-9 & N/D & N/D & N/D & AY283199 \\
Brazil-12 & N/D & N/D & N/D & AY283200 \\
UFMG-1 & N/D & N/D & N/D & EU676175 \\
UFMG-2 & N/D & N/D & & EU676176 \\
\hline Not & & &
\end{tabular}

N/D: Not Defined.

Table 3. The msp1 $\alpha$ microsatellite sequences were analyzed in 13 A. marginale isolates. The microsatellite (sequence in bold) was located between the Shine-Dalgarno (SD; sequence in brackets) and the translation initiation codon (ATG) with the structure: GTAGG (G/ATTT)m (GT)n T ATG. The SD-ATG distance was calculated in nucleotides as $(4 \mathrm{xm})+(2 \mathrm{xn})+1$.

\begin{tabular}{lcccc}
\hline \multicolumn{1}{c}{ Isolates } & Genotype & $\mathbf{m}^{*}$ & $\mathbf{n}^{* *}$ & $\begin{array}{c}\text { SD-ATG distance } \\
\text { (nucleotide) }\end{array}$ \\
\hline Minas-1 & $\mathrm{E}$ & 2 & 7 & 23 \\
Minas-2 & $\mathrm{E}$ & 2 & 7 & 23 \\
Minas-3 & $\mathrm{E}$ & 2 & 7 & 23 \\
Minas-4 & $\mathrm{G}$ & 3 & 5 & 23 \\
Minas-5 & $\mathrm{B}$ & 1 & 9 & 23 \\
Minas-6 & $\mathrm{E}$ & 2 & 7 & 23 \\
Minas-7 & $\mathrm{D}$ & 2 & 6 & 21 \\
Minas-8 & $\mathrm{E}$ & 2 & 7 & 23 \\
Minas-9 & $\mathrm{D}$ & 2 & 6 & 21 \\
Minas-10 & $\mathrm{E}$ & 2 & 7 & 23 \\
Minas-11 & $\mathrm{E}$ & 2 & 7 & 23 \\
Minas-12 & $\mathrm{E}$ & 2 & 7 & 23 \\
Minas-13 & $\mathrm{E}$ & 2 & 7 & 23 \\
Brazil & $\mathrm{G}$ & 3 & 5 & 23 \\
Brazil-5 & $\mathrm{D}$ & 2 & 6 & 21 \\
Brazil-9 & $\mathrm{C}$ & 2 & 5 & 19 \\
Brazil-12 & $\mathrm{E}$ & 2 & 7 & 23 \\
\hline
\end{tabular}

${ }^{*} \mathrm{~m}$ is the number of repetitions of the nucleotide sequence G/A TTT. ${ }^{*} \mathrm{n}$ is the number of repetitions of the nucleotide sequence GT.

in Minas Gerais, but had been detected in Argentina, Mexico, South Africa and Israel (DE LA FUENTE et al., 2007), and one was a new sequence when compared with the tandem repeats reported worldwide for $A$. marginale MSP1a.

\begin{tabular}{|c|c|c|c|c|c|c|}
\hline Isolates & Struct & ure o & Ms & la t & indem repeats & No. of repeats \\
\hline Minas-1 & $\tau$ & 57 & $\beta$ & $\beta$ & $\gamma$ & 5 \\
\hline Minas-2 & Is9 & 24 & 24 & 25 & 31 & 5 \\
\hline Minas-3 & $\alpha$ & $\beta$ & $\beta$ & $\gamma$ & & 4 \\
\hline Minas-4 & B & $\mathrm{Q}$ & $\mathrm{B}$ & $\mathrm{M}$ & & 4 \\
\hline Minas-5 & 13 & 27 & 27 & 27 & & 4 \\
\hline Minas-6 & 72 & 62 & 61 & & & 3 \\
\hline Minas-7 & 72 & 62 & 61 & & & 3 \\
\hline Minas-8 & 72 & 62 & 61 & & & 3 \\
\hline Minas-9 & 72 & 62 & 61 & & & 3 \\
\hline Minas-10 & 72 & 62 & 61 & & & 3 \\
\hline Minas-11 & $\tau$ & 57 & 13 & 18 & & 4 \\
\hline Minas-12 & 72 & 62 & 61 & & & 3 \\
\hline Minas-13 & $\alpha$. & $\beta$ & $\beta$ & 13 & & 4 \\
\hline Brazil & $\mathrm{B}$ & $\mathrm{B}$ & $Q$ & $\sigma$ & $\mu$ & 5 \\
\hline Brazil-5 & $\mathrm{C}$ & $F$ & $\mathrm{~N}$ & & & 3 \\
\hline Brazil-9 & $\alpha$. & $\beta$ & $\tau$ & $\mathrm{M}$ & & 4 \\
\hline Brazil-12 & $\alpha$ & $\beta$ & $\beta$ & $\mathrm{N}$ & & 4 \\
\hline UFMG-1 & 13 & 42 & 13 & 18 & & 4 \\
\hline UFMG-2 & 13 & 27 & 27 & & & 3 \\
\hline
\end{tabular}

Figure 2. The structure of the MSP1a repeat regions, according to the nomenclature proposed by De la Fuente et al. (2007).

Interestingly, the tandem repeats $\sigma, \mathrm{C}, \mathrm{F}, \mathrm{N}, \mu$ and 42 , previously already reported in Minas Gerais (DE LA FUENTE et al., 2007), were not found in the MSP1a sequences analyzed in this study (Figure 2). 
Using the $0.8 \mathrm{~Kb}$ fragment of MSP1a a maximum likelihood tree was built. The tree shows clusters among the different isolates from Minas Gerais and the phylogenetic relationship between them. Four clusters of MSP1a genes were found as shown in the phylogenetic tree (Figure 3).

\section{Discussion}

The analysis of MSP1a repeats sequences, which has provided evolutionary information about geographically distinct $A$. marginale strains (DE LA FUENTE et al., 2001, 2005, 2007), was used in the present study to characterize pathogen genetic diversity within a Brazilian dairy farm.

The results reported here confirm the presence of $A$. marginale infections among all age groups tested, and demonstrate that calves acquire the infection shortly after birth, suggesting that there is endemic stability for anaplasmosis in this dairy farm. On the other hand, the results reveal the presence of several $A$. marginale msp $1 a$ genotypes within the herd (Table 2). These results are consistent with the findings of high $A$. marginale genetic diversity in endemic areas worldwide (DE LA FUENTE et al., 2007).

MSP1a contains a variable number of tandemly repeated peptides in the amino-terminal region, while the remainder of the protein is highly conserved between isolates. The number of repeats varies among geographic isolates of $A$. marginale but is constant within an isolate and has been used as a stable genetic marker of isolate identity (DE LA FUENTE et al., 2003b).

Based on analysis of MSP1a tandem repeats, we found fourteen different strains in isolates from Minas Gerais (Figure 2), eight of them reported for the first time. Comparisons with the tandem repeats previously reported for MSP1a showed one new tandem repeat sequence in this study, which has been named 72 (Figure 1), following the nomenclature proposed by De la Fuente et al. (2007).

One common structure (72-62-61) for MSP1a tandem repeats was found in six of the Minas Gerais isolates (Minas 6-10 and

Table 4. A. marginale genotype frequency of bovines infected from Minas Gerais State per breed and age of the calves.

\begin{tabular}{ccccccccc}
\hline \multirow{2}{*}{ Genotype } & \multirow{2}{*}{ Isolates } & \multicolumn{3}{c}{ Breed } & & \multicolumn{4}{c}{ Group (age range in days) } \\
\cline { 3 - 4 } \cline { 6 - 8 } & & Holstein & Jersey & & $\mathbf{1 ~ ( 1 - 7 )}$ & 2 (8-30) & 3 (31-107) & 4 (108-381) \\
\hline B & 1 & 0.00 & 1.00 & & 0.00 & 1.00 & 0.00 & 0.00 \\
D & 2 & 0.50 & 0.50 & & 0.00 & 0.50 & 0.50 & 0.00 \\
E & 9 & 0.33 & 0.66 & & 0.33 & 0.11 & 0.22 & 0.00 \\
G & 1 & 0.00 & 1.00 & & 1.00 & 0.00 & 0.00 \\
\hline
\end{tabular}

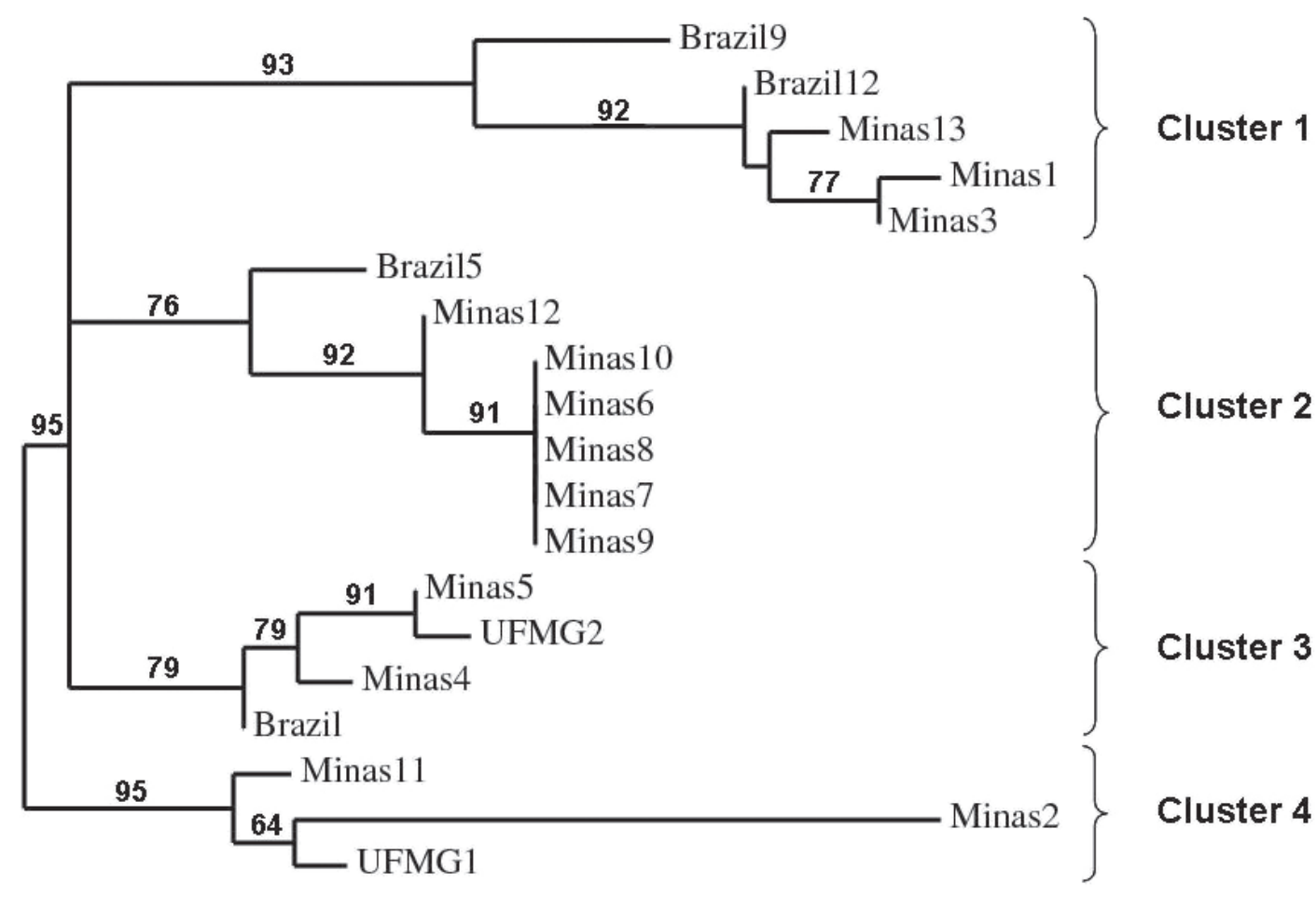

0.08

Figure 3. Unrooted phylogenetic tree based on the MSP1a protein sequences of $A$. marginale isolates from Minas Gerais. The tree shows the clusters of MSP1a. Bootstrap values are show as \% in the internal branch (only values equal or higher than $50 \%$ ). 
Minas 12), representing the most frequent strain in our study. The maximum likelihood phylogenetic tree shows that the MSP1a from Minas Gerais falls into four separated clusters. The tandem repeats 72-62-61 and C-F-N, contained in the isolate Brazil-5, reveal minor changes in amino acids (data not shown) and the phylogenetic tree shows that they fall in the same Cluster (Cluster 2 ), suggesting a common ancestor for both isolates. All the isolates containing at least one tandem repeat type $\beta$ fall in the MSP1a Cluster 1 based on the phylogenetic tree, supporting the idea that strains containing the tandem repeat type $\beta$ have common origins in Minas Gerais. Two of the strains containing tandem repeat type $\beta$ found in our study, Minas- 1 and Minas-3, belonged to animals with congenital $A$. marginale.

The phylogeographic clustering of some genotypes of the MSP1a microsatellite has been reported. The genotype $\mathbf{B}$ was exclusively associated with areas of southern Brazil but genotypes $\mathbf{C}, \mathbf{D}, \mathbf{E}$ and $\mathbf{G}$ have been also found in other geographic regions (ESTRADA-PEÑA et al., 2009).

The five genotypes found in Minas Gerais isolates were previously reported for this geographic region. The predominant genotype $\mathbf{E}$ was present in all of the phylogenetic clusters of MSP1a except for Cluster 3. The length of the MSP1 a microsatellite could have affected the expression of MSP1a, thus influencing the infection and transmission of $A$. marginale. Higher expression levels were reported for SD-ATG distances of 23 and 29 nucleotides and lower expression for 19 nucleotides (ESTRADA-PEÑA et al., 2009). Almost all the tandem repeats found in the present study were 21 or 23 nucleotides long. It is noteworthy that all the SDATG distances in the congenitally transmitted $A$. marginale were 23 nucleotides. This suggests a high capacity for infection and transmission of the $A$. marginale strains found in this area and particularly of the isolates transmitted congenitally.

Based on the analysis of MSP1a microsatellite and tandem repeat structure we found a high genetic diversity in the Minas Gerais $A$. marginale isolates. The genetic diversity of $A$. marginale MSP1a could be explained not only by evolutionary pressures exerted by ligand-receptor and host-parasite interactions (DE LA FUENTE et al., 2001) but also by constant movements of cattle or independent transmission (DE LA FUENTE et al., 2005). In the case of this farm, evolutionary pressure and independent transmission should be the main explanations for the genetic diversity, since no new animals had been introduced into the herd over the previous 20 years. Nevertheless, one animal with congenital A. marginale (isolate Minas-3) had a tandem repeat structure previously reported in Mexico (DE LA FUENTE et al., 2001).

Regarding congenital transmission, each of the four infected newborn calves carried a different strain of $A$. marginale (Minas- 1 to -4 ) (Figure 2), but only two genotypes, $\mathbf{E}$ and $\mathbf{G}$, based on the msp $1 \alpha$ microsatellites (Table 3 ). The genotype $\mathbf{E}$ predominated in this and the other age groups, showing it to be the predominant genotype at the study site. This genotype was found in one sequence previously reported in Minas Gerais (Brazil-12) (Table 3).

\section{Conclusions}

From the results presented here we can conclude that (1) genetic diversity of $A$. marginale is high in Minas Gerais and (2) congenital transmission appears to be an important phenomenon that contributes to the persistence of several $A$. marginale strains within a herd. Further investigations should address the influence of such elevated genetic variation of $A$. marginale strains on epidemiological aspects of bovine anaplasmosis. This might contribute to a better understanding of the epidemiology of the disease and consequently to the development and implementation of appropriate control and prevention measures.

\section{Acknowledgements}

The authors are grateful to Camila V. Bastos (UFMG, Belo Horizonte, Brazil), Evelyn Overzier, Claudia Thiel, Tim Tiedemann and Katarzyna Lis (Institute for Comparative Tropical Medicine and Parasitology, LMU-München, Germany) for their excellent technical assistance, and to Lesley Bell-Sakyi (The Pirbright Institute, Surrey, UK) for revising the English language of the manuscript. Alejandro Cabezas-Cruz is a Marie Curie Early Stage Researcher supported by the POSTICK ITN (Post-graduate training network for capacity building to control ticks and tick-borne diseases) within the FP7-PEOPLE - ITN programme (EU Grant No. 238511).

\section{References}

Anisimova M, Gascuel O. Approximate likelihood-ratio test for branches: A fast, accurate, and powerful alternative. Syst Biol 2006; 55(4): 539-552. PMid:16785212. http://dx.doi.org/10.1080/10635150600755453

Aubry P, Geale DW. A Review of Bovine Anaplasmosis. Transbound Emerg Dis 2011; 58(1): 1-30. PMid:21040409. PMid:21040409.

Carelli G, Decaro N, Lorusso A, Elia G, Lorusso E, Mari V, et al. Detection and quantification of Anaplasma marginale DNA in blood samples of cattle by real-time PCR. Vet Microbiol 2007; 124(1-2): 107-114. PMid:17466470. PMid:17466470.

Castresana J. Selection of conserved blocks from multiple alignments for their use in phylogenetic analysis. Mol Biol Evol 2000; 17(4): 540-552. PMid:10742046. http://dx.doi.org/10.1093/oxfordjournals.molbev. a026334

Chevenet F, Brun C, Bañuls AL, Jacq B, Chisten R. TreeDyn: towards dynamic graphics and annotations for analyses of trees. BMC Bioinf 2006; 10(7): 439. PMid:17032440 PMCid:1615880. http:// dx.doi.org/10.1186/1471-2105-7-439

De la Fuente J, Garcia-Garcia JC, Blouin EF, Rodriguez SD, García MA, Kocan KM. Evolution and function of tandem repeats in the major surface protein 1a of the ehrlichial pathogen Anaplasma marginale. Anim Helth Res Rev 2001; 2(2): 163-173. PMid:11831437. PMid:11831437.

De la Fuente J, Van Den Bussche RA, Garcia-Garcia JC, Rodríguez SD, García MA, Guglielmone AA, et al. Phylogeography of New World isolates of Anaplasma marginale based on major surface protein sequences. Vet Microbiol 2002; 88(3): 275-285. PMid:12151201. PMid:12151201.

De la Fuente J, Van Den Bussche RA, Prado TM, Kocan KM. Anaplasma marginale mspla genotypes evolved under positive selection pressure but are not markers for geographic strains. J Clin Microbiol 2003a; 41(4): 1609-1616. PMid:12682152. PMid:12682152.

De la Fuente J, Garcia-Garcia JC, Blouin EF, Kocan KM. Characterization of the functional domain of major surface protein 1a involved in 
adhesion of the rickettsia Anaplasma marginale to host cells. Vet Microbiol2003b; 91(2-3) 265-283. PMid: 12458174. PMid: 12458174.

De la Fuente J, Lew A, Lutz H, Meli ML, Hofmann-Lehmann R, Shkap V, et al. Genetic diversity of Anaplasma species major surface proteins and implications for anaplasmosis serodiagnosis and vaccine development. Anim Health Res Rev 2005; 6(1): 75-89. PMid:16164010. PMid:16164010.

De la Fuente J, Ruybal P, Mtshali MS, Naranjo V, Shuqing L, Mangold AJ, et al. Analysis of world strains of Anaplasma marginale using major surface protein 1a repeat sequences. Vet Microbiol 2007; 119(2-4): 382-390. Pmid:17084044.

Edgar RC. MUSCLE: multiple sequence alignment with high accuracy and high throughput. Nucleic Acids Res 2004; 32(5): 1792-1797. PMid:15034147 PMCid:390337. http://dx.doi.org/10.1093/nar/ gkh340

Estrada-Peña A, Naranjo V, Acevedo-Whitehouse K, Mangold AJ, Kocan KM, De la Fuente J. Phylogeographic analysis reveals association of tick-borne pathogen, Anaplasma marginale, MSP1a sequences with ecological traits affecting tick vector performance. BMC Biol 2009; 7:57. PMid:19723295 PMCid:2741432. http://dx.doi.org/10.1186/17417007-7-57

ExPaSy Translation Tool 2011. Available from: http://expasy.hcuge.ch/ tools/dna.html.

Guindon S, Gascuel O. A simple, fast, and accurate algorithm to estimate large phylogenies by maximum likelihood. Syst Biol2003; 52(5): 696-704. PMid:14530136. http://dx.doi.org/10.1080/10635150390235520

Kessler RH, Schenk MAM. Carrapato, tristeza parasitária e tripanossomose dos bovinos. EMBRAPA; 1998.
Kocan KM, De la Fuente J, Guglielmone AA, Melendez RD. Antigens and alternatives for control of Anaplasma marginale infection in cattle. Clin Microbiol Rev 2003; 16(4): 698-712. PMid:14557295 PMCid:207124. http://dx.doi.org/10.1128/CMR.16.4.698-712.2003

Lew AE, Bock RE, Minchin CM, Masaka S. A msp1a polymerase chain reaction assay for specific detection and differentiation of Anaplasma marginale isolates. Vet Microbiol 2002; 86(4): 325-335. Pmid:11955782.

Palmer GH, Brown WC, Rurangirwa FR. Antigenic variation in the persistence and transmission of the ehrlichia Anaplasma marginale. Microbes Infect 2000; 2(2): 167-176. PMid:10742689. PMid:10742689.

Passos LMF, Lima JD. Diagnóstico de anaplasmose bovina congênita em Minas Gerais. Arq Bras Med Vet Zootec 1984; 36(6): 743-744.

Ribeiro MFB, Reis R. Natural exposure of calves to Anaplasma marginale in edemic areas of Minas Gerais. Arq Bras Med Vet Zootec 1981; 33(1): 63-66.

Ribeiro MFB, Passos LMF. Tristeza parasitária bovina. Cad Tec Vet Zootec 2002; 39: 36-52.

Thompson JD, Higgings DG, Gibson TJ. CLUSTALW: improving the sensitivity of progressive multiple sequence alignment through sequence weighting, position-specific gap penalties and weight matrix choice. Nucleic Acids Res 1994; 22(22): 4673-4680. PMid:7984417 PMCid:308517. http://dx.doi.org/10.1093/nar/22.22.4673

Zaugg JL, Kuttler KL. Bovine anaplasmosis: in utero transmission and the immunologic significance of ingested colostral antibodies. Am J Vet Res 1984; 45(3): 440-443. PMid:6711971.

Zhang Z, Schwartz S, Wagner L, Miller W. A greedy algorithm for aligning DNA sequences. J Comput Biol 2000; 7(1-2): 203-214. PMid:10890397. http://dx.doi.org/10.1089/10665270050081478 